\title{
Устойчивость образцов яровой твердой пшеницы КАСИБ к возбудителю желтой ржавчины
}

Шайдаюк Е.Л. *, м.н.с.; Гультяева Е.И., д.б.н., в.н.с. Всероссийский НИИ защиты растений, Санкт-Петербург, Россия. *e-mail: eshaydayuk@bk.ru

Изучена проростковая устойчивость к возбудителю желтой ржавчины у 25 образиов яровой твердой пшеницы, полученных из КазахстанскоСибирской сети улучшения яровой пшенищы (КАСИБ). Выделены образиы устойчивые к популяциям возбудителя желтой ржавчины широкого географического происхождения.

Ключевые слова: Pиссіпіа striiformis, Triticum durum, устойчивость, Yr-гены.

\section{Resistance of common spring wheat samples to yelow rust}

Shaydayuk Ekaterina L'vovna, Gultyaeva Elena Ivanovna, All-Russian Institute of Plant Protection, Saint-Petersburg, Russia eshaydayuk@bk.ru

Resistance to yellow rust causative agent was studied in 25 samples of spring durum wheat obtained from the Kazakhstan-Siberian Network for Wheat Improvement (KASIB) at the seedling stage. Samples resistant to geographically distant yellow rust populations have been revealed.

Key words: Puccinia striiformis, Triticum durum, resistance, Yr-genes.

Желтая ржавчина (возбудитель Puccinia striiformis Westend. f. sp. tritici) относится к группе потенциально опасных болезней пшеницы в России. До 2000-х годов она представляла значимость только в предгорных районах Северного Кавказа. В современный период зоны распространения заболевания существенно расширились. Практически ежегодно заболевание отмечается в посевах озимой пшеницы в Северо-Кавказском регионе [1] и периодически в центрально-европейской части и на Северо-Западе России [2]. В 2018-2019 гг. желтая ржавчина встречалась на посевах яровой мягкой и твердой пшеницы в Омской области, а в 2019 году была отмечена в Новосибирской (устное сообщение Пискарев В.В., СибНИИРС - филиал ИЦиГ CO РAH).

Проявляется заболевание в виде лимонно-желтых урединиопустул, расположенных вдоль жилок листа. При сильном развитии болезни могут быть поражены колосковые чешуи. Данный вид ржавчины считается более вредоносным, по сравнению с бурой и стеблевой. В связи с этим, в совре- 
менный период ей уделяется особое внимание во всем мире. Высокая миграционная способность $P$. striiformis обуславливает распространение спор на длительные расстояния [3]. Justesen с соавторами [4] доказали возможность миграции спор патогена по всей территории Западной Европы. Аналогичные сведения получены для других регионов мира (США, Китай Северная и Южная Африка).

Возбудитель желтой ржавчины в современный период успешно адаптировался к высоким температурам, в связи с чем, ареал ее существенно расширился. У новых рас отмечено сокращение латентного периода, повышенная спорообразующая способность и агрессивность, по сравнению с расами P. striiformis, отмечаемыми до 2000 годов [5].

Высокий эволюционный потенциал возбудителя желтой ржавчины предопределяет проведение опережающей селекции на устойчивость к данному патогену. Целью работы являлась оценка ювенильной устойчивости линий яровой твердой пшеницы КАСИБ-2019 к популяциям P. striiformis широкого географического происхождения.

Материалом исследований служили 25 образцов яровой твердой пшеницы, переданных из Казахстанско-Сибирской сети улучшения яровой пшеницы (КАСИБ) в 2019 году. Для инокуляции использовали 12-14 дневные растения, которые опрыскивали водной суспензией урединиоспор с добавлением детергента Твин-80. Для инокуляции использовали географически отдаленные популяции P. striiformis, которые были получены с мягкой пшеницы в Северо-Кавказском (Краснодарский край) (СК), Западно-Сибирском (Новосибирская обл.) (ЗС) и Северо-Западном (Ленинградская обл.) (СЗ) регионах. В Ленинградской области листья с урединиопустулами были также собраны и на твердой пшенице. Все популяции были размножены в лабораторных условиях и охарактеризованы по вирулентности к линиям Avocet c генами устойчивости к желтой ржавчине $(\mathrm{Yr})$. Концентрация спор в суспензии составляла $1 \times 10^{6}$ спор/мл. После инокуляции растения плотно закрывали полиэтиленовым каркасом для создания влажной камеры и переносили в камеру искусственного климата Versatille Environmental Test Chamber MLR352H («SANYO Electric Co., Ltd.», Япония), где выдерживали в темноте при температуре $10{ }^{\circ} \mathrm{C}$ в течение 16 часов. Далее каркасы снимали, и растения инкубировали на свету в течение 16 часов при температуре $16^{\circ} \mathrm{C}$ и влажности $70 \%$, и затем в течение 8 часов в темноте при температуре $10{ }^{\circ} \mathrm{C}$ и влажности $75 \%$. Учет типа реакции проводили на 18-20 день после заражения с использованием шкалы McNeal с соавторами (1971) [6], где 0 - отсутствие симптомов; 1 - некротические следы; 2 - некротические пятна без урединиопустул; 3-4 - слабо спорулирующие урединиопустулы, окруженные некрозами и хлорозами; 5-6 - умеренно спорулирующие урединиопустулы с зоной хлороза и некроза; 7-8 - спорулирующие урединиопустулы с хлорозом; 9 - обильно спорулирующие пустулы без хлороза. Растения с баллами 
0-6 относили к устойчивым, с баллами 7-9 к восприимчивым [7].

С использованием молекулярных маркеров провели идентификацию генов $\quad Y r 9$ (SCM9), $\quad \operatorname{Yr} 17$ (маркер Ventriup/LN2) и $\quad Y r 18$ (csLV34) (https://maswheat.ucdavis.edu).

При инокуляции популяциями широкого географического происхождения устойчивость (тип реакции от 0 до 6 балла) ко всем из них выявлена у шести (24 \%) образцов твердой пшеницы: Р-1409, Сояна, Сеймур 17, Гордеиформе 1790, Гордеиформе 910 и Линия Д-2165 (таблица). Семь образцов $(28 \%)$ показали устойчивость ко всем популяциям с мягкой пшеницы (СК, 3С, С3), но были восприимчивы к ленинградской популяции с твердой пшеницы. К ним относились сорта Янтарная 60, Серке, Меляна, Безенчукская 139 и линии 69-08-2, Гордеиформе 895, Гордеиформе 924. Сорта Гордея, Целинная и линия 2021д-1 были устойчивы к краснодарской и новосибирской популяциям P. striiformis и восприимчивы к северо-западным с твердой и мягкой пшеницы.

Выявлены различия в типе реакции при инокуляции образцов твердой пшеницы популяциями патогена с твердой и мягкой пшеницы. Инокулюм с твердой пшеницы был более вирулентным для твердой пшеницы, чем с мягкой. Только пять образцов твердой пшеницы (20\%) показали умеренно устойчивый тип реакции (балл 5-6) при инокуляции ленинградской популяцией с твердой пшеницы. При заражении ленинградской популяцией патогена с мягкой пшеницы количество устойчивых было существенно выше (13 образцов, $52 \%)$.

Таблица - Устойчивость образцов яровой твердой пшеницы к возбудителю желтой ржавчины в фазе проростков

\begin{tabular}{|c|c|c|c|c|c|c|}
\hline \multirow{2}{*}{$\begin{array}{l}\text { № } \\
\text { п/п }\end{array}$} & \multirow{2}{*}{$\begin{array}{l}\text { Название } \\
\text { сорта/линии }\end{array}$} & \multirow{2}{*}{ Оригинатор } & \multicolumn{4}{|c|}{$\begin{array}{c}\text { Тип реакции к популяциям } \\
\text { P. striiformis в фазе проростков }\end{array}$} \\
\hline & & & СК & $3 \mathrm{C}$ & $\begin{array}{c}\mathrm{C} 3 \mathrm{c} \\
\text { T.aestivum } \\
\end{array}$ & $\begin{array}{c}\mathrm{C} 3 \mathrm{c} \\
\text { T.durum }\end{array}$ \\
\hline 1 & 2 & 3 & 4 & 5 & 6 & 7 \\
\hline 1 & P-1409 & $\begin{array}{l}\text { Актюбинская } \\
\text { СХОС }\end{array}$ & $1-2$ & 0 & 0 & 5 \\
\hline 2 & Сояна & - & $0-1$ & 0 & 0 & $5-6$ \\
\hline 3 & Янтарная 60 & - & 1 & 0 & 0 & 8 \\
\hline 4 & Сеймур 17 & КазНИИЗиР & 5 & 0 & $5-6$ & 6 \\
\hline 5 & Серке & - & 5 & 0 & $0-1$ & $6-7$ \\
\hline 6 & Линия 69-08-2 & $\begin{array}{l}\text { НПЦЗХ им. } \\
\text { А.И.Бараева }\end{array}$ & 2 & 0 & 0 & $6-7$ \\
\hline 7 & Линия 250-06-14 & - & $6-7$ & $7-8$ & $6-7$ & 7 \\
\hline 8 & Костанайская 15 & $\begin{array}{c}\text { Карабалыкская } \\
\text { СХОС }\end{array}$ & $6-7$ & 7 & 7 & 7 \\
\hline 9 & Гордеиформе 1790 & - & 1 & 0 & 0 & 5 \\
\hline 10 & Линия №9 & - & $6-7$ & $7-8$ & 7 & $6-7$ \\
\hline
\end{tabular}




\begin{tabular}{|c|l|c|c|c|c|c|}
\hline $\mathbf{1}$ & \multicolumn{1}{|c|}{$\mathbf{3}$} & $\mathbf{4}$ & $\mathbf{5}$ & $\mathbf{6}$ & $\mathbf{7}$ \\
\hline 11 & Гордеиформе 895 & $\begin{array}{c}\text { Алтайский } \\
\text { НИИСХ }\end{array}$ & 1 & 0 & 0 & $6-7$ \\
\hline 12 & Гордеиформе 910 & - & 0 & 0 & 0 & $5-6$ \\
\hline 13 & Гордеиформе 924 & - & 0 & 0 & 0 & $7-8$ \\
\hline 14 & Гордеиформе 08-25-2 & СибНИИСХ & $6-7$ & 7 & 7 & 7 \\
\hline 15 & Гордеиформе 08-67-1 & - & 7 & $6-7$ & 7 & 7 \\
\hline 16 & Гордеиформе 08-107-5 & - & 8 & $6-7$ & 7 & 7 \\
\hline 17 & Линия 1693д-71 & $\begin{array}{c}\text { Самарский } \\
\text { НИИСХ }\end{array}$ & $6-7$ & $6-7$ & 7 & 7 \\
\hline 18 & Линия 1970д-5 & - & 7 & $7-8$ & 7 & 7 \\
\hline 19 & Линия 2021д-1 & - & 3 & $1-2$ & 7 & $6-7$ \\
\hline 20 & Гордеиформе 1591-21 & - & 7 & $6-7$ & 7 & $7-8$ \\
\hline 21 & Линия Д-2165 & $\begin{array}{c}\text { НИИСХ Юго- } \\
\text { Востока }\end{array}$ & 4 & 0 & $1-2$ & $5-6$ \\
\hline 22 & Гордея & Оренбургский & 3 & $1-2$ & 7 & 7 \\
\hline 23 & Целинная & - & $3-4$ & 0 & 7 & 7 \\
\hline 24 & Меляна & - & 3 & 0 & 0 & 7 \\
\hline 25 & Безенчукская 139 & Стандарт & 5 & 0 & 0 & $6-7$ \\
\hline
\end{tabular}

С использованием молекулярных маркеров у изучаемых образцов твердой пшеницы не выявлено генов $\operatorname{Yr} 9$, $\operatorname{Yr} 17$ и $\operatorname{Yr} 18$. Полученные данные молекулярного тестирования согласуются с фитопатологическим тестом. Используемые в данной работе популяции были вирулентны к линиям с генами $\operatorname{Yr} 9$ и $\operatorname{Yr} 18$ и авирулентны к $\operatorname{Yr} 17$ (тип реакции 0).

Варьирование типа реакции у образцов твердой пшеницы к используемым популяциям возбудителя желтой ржавчины указывает на расоспецифический тип их устойчивости, а также различия патогена по вирулентности в географически отдаленных регионах (Западной Сибири, Северном Кавказе и Северо-Западе). Полученные сведения следует учитывать в селекции на устойчивость твердой пшеницы к болезням.

19-76-30005.

Благодарности: Работа выполнена при поддержке проекта РНФ №

\section{Список литературы}

1. Волкова Г.В. Желтая ржавчина пшеницы на Кубани / Г.В. Волкова, Л.Н. Шуляковская, О.А. Кудинова, И.П.Матвеева // Защита и карантин растений. 2018. - №4. - С.22.

2. Гультяева Е.И. Болезни зерновых культур и рапса в Северо-западном регионе в 2016 г / Е.И. Гультяева, Е.Л. Гасич, М.М. Левитин, И.В. Маслова, О.А. Колесникова, М.П. Вусатюк, Е.Л. Шайдаюк, М.М. Гомжина, Н.П. Шипилова / Защита и карантин растений. - 2017. - №4. - С. 27-29.

3. Chen, W. Wheat stripe (yellow) rust caused by Puccinia striiformis f. sp. tritici / W.Chen, C. Wellings, X. Chen, Z. Kang, T. Liu / Molecular Plant Pathology. - 2014. - V. 
15(5). - P. 433-446. DOI: 10.1111/mpp.12116.

4. Justesen, A.F. The recent history of Puccinia striiformis f. sp. tritici in Denmark as revealed by disease incidence and AFLP markers / A.F. Justesen, C.J. Ridout, M.S. Hovmøller // Plant Pathology. - 2002. - V. 51. - P. 13-23.

5. Milus, E.A. Evidence for increased aggressiveness in a recent widespread strain of Puccinia striiformis f. sp. tritici causing stripe rust of wheat / E.A. Milus, K. Kristensen, , \& M.S. Hovmøller / Phytopathology. - 2009. - V. 99(1). - P. 89-94. DOI: 10.1094/PHYTO-99-1-0089).

6. McNeal F. H. A uniform system for recording and processing cereal research data / F. H. McNeal, C. F Konzak, E. P. Smith, W. S. Tate, T. S. Russell / U.S. Dept. Agric., Agric. Res. Serv, 1971. - ARS 34-121. - 42 pp.

7. McIntosh, R.A. Catalogue of gene symbols for wheat: 2005 supplement R.A. McIntosh1, K.M. Devos2, J. Dubcovsky3, W.J. Rogers4, C.F. Morris5, R. Appels6, and O.D. Anderson. - 2005. Режим доступа:

https://shigen.nig.ac.jp/wheat/komugi/genes/macgene/supplement2005.pdf

DOI 10.18699/GPB2020-73

\section{Создание исходного материала для селекции в Омском ГАУ с использованием синтетической пшеницы}

Шаманин В.П. ${ }^{{ }^{*}}$, д.с.-х.н., профессор; Потоикая И.В. ${ }^{l}$, к.с.-х.н., доиент; Шепелев С.С. ${ }^{1}$, к.с.-х.н., зав. лаб.; Чурсин А.С. ${ }^{1}$, зав. лаб.; Пожерукова В.Е. к.б.н., н.с.; Гладких М.С. ${ }^{1}$, к.с.-х.н., н.с., Моргунов А.И. ${ }^{2}$ к.с.-х.н., адьюнктпреподаватель.

${ }^{1}$ ФГБОУ ВО Омский ГАУ, Омск, Россия,

${ }^{2}$ Университет штата Вашингтон, Пулман, США.

*e-mail:vp.shamanin@omgau.org

Проведена фенотипическая оценка исходного материала яровой мягкой пшеницы, полученного на основе гексаплоидной синтетической пиеницы с геномом Aegilops tauschii селекции CIMMYT в условиях южной лесостепи Западной Сибири. Показана селекционная ценность линий с генетическим материалом синтетической пшеницы для повышения урожайности и качества зерна сортов пиеницы.

Ключевые слова: синтетическая пшеница, признаки продуктивности растения, качество зерна, КАSP-маркеры.

\section{Creation of initial material for breeding in Omsk SAU on the basis of synthetic wheat}

Shamanin Vladimir Petrovich ${ }^{1}$, Pototskaya Inna Vladimirovna ${ }^{l}$, Shepelev Sergey Sergeevich $^{l}$, Chursin Aleksandr Sergeevich ${ }^{l}$, Pozherukova Violetta Evgenievna ${ }^{l}$, Gladkih Marina Sergeevna ${ }^{l}$, Morgunov Alexey Ivanovich ${ }^{2}$ 